\title{
CORAL ReEFs AND BIODIVERSITY: A CRITICAL AND THREATENED RELATIONSHIP
}

\author{
By J.E. Maragos, M.P. Crosby \\ and J.W. McManus
}

\begin{abstract}
$\mathrm{T}$ HE IMPORTANCE OF coral reef ecosystems may be seen in their numerous ecological, aesthetic, economic, and cultural functions. Atoll and barrier reef islanders recognize that healthy reefs are essential for the support, creation, and repair of the coral islands on which they live. Coral reefs also protect coastlines from shoreline erosion and serve as a living pantry for the subsistence harvest and consumption of many reef organisms. The cycle of reef accretion and erosion maintains beaches and provides habitat for seagrasses and mangroves. Coral reefs are important recreational resources for most of the worlds people having the privilege of living near them. In the modern era, coral reefs passes and channels provide safe navigation channels for boats, and harbors are often sighted on reefs because they provide natural protection from heavy wave action. Coral reefs are fast becoming the main attraction for visitors to many tropical island and coastal destinations. Coral reefs are also the favorite sites of many governments and developers for construction materials, and reef rock is mined in many countries to provide armor stone and building materials. Few aspects of these activities, especially modern uses, are beneficial to reefs, and scientists and other reef users are beginning to realize that coral reefs are fragile and are now threatened in many areas in the world from chronic anthropogenic reef disturbance. The ability of coral reef ecosystems to exist in balanced harmony with other naturally occurring competing/limiting physicochemical and biological agents has been severely challenged in the last several decades by the
\end{abstract}

J.E. Maragos, Program on Environment. East West Center. Honolulu. HI. USA. M.P. Crosby. Ocean and Coastal Resource Management, National Oceanic and Atmospheric Administration. 1305 East West Highway, Rm. 11437. Silver Spring, MD 20910, USA. J.W. McManus, Coastal \& Coral Reef Resource Systems Program, International Center for Living Aquatic Resources Management. Manila. Philippines (ICLARM \#1247). All correspondence should be directed to M.P. Crosby. This manuscript reflects the opinions of the authors and is not meant to represent the official policy of any government agency. dramatically increased negative and synergistic impacts from poorly managed anthropogenic activities. Globally, scientists are now working together and with other groups to promote assessment, monitoring, other research, protection, and restoration of coral reefs. Establishment of coral reef management initiatives at the local community, national, and regional levels are essential for long-term sustainable use and conservation of these critically important habitats. The focus of these initiatives should be on assisting culturally, economically, and politically diverse peoples around the world in their development of integrated coastal zone management with emphasis on local community involvement and leadership.

\section{Introduction}

Most of what we have learned about coral reefs has been gathered by scientists during the past 150 years, beginning with Charles Darwin and James D. Dana in the mid-19th century (Darwin. 1842: Dana, 1872). Darwin first postulated that the subsidence of volcanic islands can result in the evolution of fringing reefs to barrier reefs and atolls (Fig. 1, a-d). Dana, as geologist aboard the U.S. Exploring Expedition (1838-1842) which circumnavigated the globe, was able to publish the first definitive global distribution of coral reefs. He also addressed some of the major factors - the need for warm seawater temperatures (generally $>21^{\circ} \mathrm{C}$ ) and light - that contribute to vigorous reef growth and described more species of corals than any other scientist beforehand or afterward. Other pioneering reef scientists through the early twentieth century included Stanley Gardiner, Alexander Agassiz, Alfred Mayor, Thomas Vaughan, Maurice Yonge, and Cyril Crossland. Important earlier expeditions and laboratories focusing on coral reefs research occurred on Bermuda, the Great Barrier Reef, the Dry Tortugas, and in Palau. The more recent use of drilling equipment, submersibles, scuba equipment. modern laboratory equipment. and other technological innovations ushered in the era of modern coral reef research and inquiry, beginning with works of John Wells. Joshua Tracey, and Harry Ladd, and
The ability of coral

reef ecosystems to exist in balanced harmony with other naturally occurring competing/limiting physicochemical and biological agents has been severely challenged in the last several decades by the dramatically increased negative and synergistic impacts from poorly managed anthropogenic activities. 
$\mathrm{N}$

coral reef structure

itself composed of

and built by a diver-

sity of organisms, but

the reef structure

serves as the basis

for one of the highest

diversity ecosystems

in the world. . . co-workers on several atolls in the Marshall Islands beginning in the 1940s, and with Thomas Goreau, in Jamaica, beginning in the late 1950s. Drilling expeditions to Funafuti (in Tuvalu), in 1898 and Enewetak (in the Marshalls) in the 1940s and early 1950 s revealed that present day atolls have sustained continuous upward reef growth of up to $\geq 1.000 \mathrm{~m}$ over periods of 50 million years or more.

Coral reefs are accumulations of the biogenous remains of carbonate secreting reef organismsboth plants and animals that formed in warm tropical (and in some cases, semitropical) seas. The principal reef builders are referred to as "hermatypic" corals. These corals exist in a symbiotic relationship with microscopic unicellular algae know as "zooxanthellae." The coral-algal symbiotic association aids the formation of massive reefs because of the unique advantages of the association. The symbiotic algae are protected in the tissues of the coral animals that are themselves protected by highly specialized stinging cells, the nematocysts. These animals can also depend on the algae for most or all of their food supply. whereas the algae can depend on the animals for nutrients and carbon dioxide for photosynthesis. This symbiotic relationship is widely believed to greatly increase calcification and improve energy and nutrient fluxes between the animals and the plants, allowing more rapid coral growth and the corresponding opportunity for more rapid reef growth. However, the exact nature of this relationship has recently been questioned (Marshall, 1996).

The coral recf structure itself is a thin veneer of living reef organisms that overlays the remains of generations of progressively older reef organisms. In fact, most of the major coral reefs observed today are living veneers that have covered previously existing substrates only within the last 10.000 years. The accumulations are cemented together to form wave-resistant structures, capable of continued growth in the face of heavy and prevailing wave action and currents, especially along seaward reef slopes. Not all tropical coasts are able to support coral reefs. Active volcanic islands or continental coasts may be too inhospitable or unstable for corals and other reef organisms to settle and grow. If the shorelines of islands and other coasts are either sinking or emerging too quickly, then it is not possible for large reef structures and wide reef flats to form. Coastlines subjected to heavy sedimentation, freshwater flooding, or excessive storm and wave action often do not support structural coral reefs. Isolated reef communilies, banks. or patch reefs may be capable of forming in these areas, especially offshore of many large islands and continental coastlines where they sometimes occur only as submerged reefs. During periods of gradual subsidence of volcanic islands, fringing reefs may become barrier reefs if they are able to maintain upward growth to keep pace with subsidence (Fig. 1). Subsidence causes the islands (or continental coast) to shrink in size. leaving a gap (the lagoon) between the offshore reef and island shoreline. If island subsidence continues to be gradual, allowing upward reef growth, the volcanic island eventually disappears and is buried under accumulating lagoon sediments, creating an atoll with perimeter coral reefs surrounding a lagoon. Secondary reefs also form in the lagoons of barricr reefs and atolls including pinnacles, patch reefs, and lagoon fringing reefs around islands. Passes often cut through barrier and atoll reefs allowing exchange of lagoon and ocean waters, and natural channels often serve as gaps along fringing reefs where rivers and streams discharge sufficiently to discourage reef growth.

Living healthy coral reefs (i.e., Fig. 2, a-e) generally grow upward and outward (or seaward) from the submerged slopes of islands, continents. or older reefs, and are able to thrive in nutrientpoor transparent oceanic waters. If reef growth reaches sea level, then only outward growth is possible because the marine organisms forming coral reefs cannot normally live above mean low tidal levels. Continuous periods of outward reef growth creates reef flats. The inner portions of progressively wider reef flats begin to accumulate sand and other sediments that eventually may be transported to shore to form the white sand beaches that characterize many coral reef coasts. However, the seaward slope and upper edge of the reef flat usually supports the principal populations of diverse reef-building organisms-corals, calcareous/encrusting/coralline algae, and sometimes mollusks. The diversity of reef-building organisms contributing calcium carbonate materials to coral reefs also includes echinoderms, sand producing green and red algae, and foraminiferans, with worm tubes. barnacles, and other skeletal remains sometimes adding to the bulk of reef structures.

\section{Coral Reef Biodiversity and Importance}

Not only is the coral reef structure itself composed of and built by a diversity of organisms, but the reef structure serves as the basis for one of the highest diversity ecosystems in the world (Talbot. 1994). Coral reef ecosystems generally have high species diversity. although many associated species tend to exhibit low endemism and broad distributions (Norse, 1993). The coral species alone range from $>48$ in the Caribbean (Goreau and Wells. 1967) to $>700$ in the Indo-Pacific (Wells, 1957: Veron, 1986). When speaking of biological diversity, it is indeed appropriate to refer to coral reef ecosystems as the rain forests of the marine realm. Coral reefs have far greater productivity than other marine systems, surpassing 7,000 g C m 2 $\mathrm{yr}^{1}$ (Odum et al.. 1959; Helfrich and Townsley, 1965). Reef fishes, sea urchins, coralline algae, and many additional species of plants and animals contribute to healthy reef 

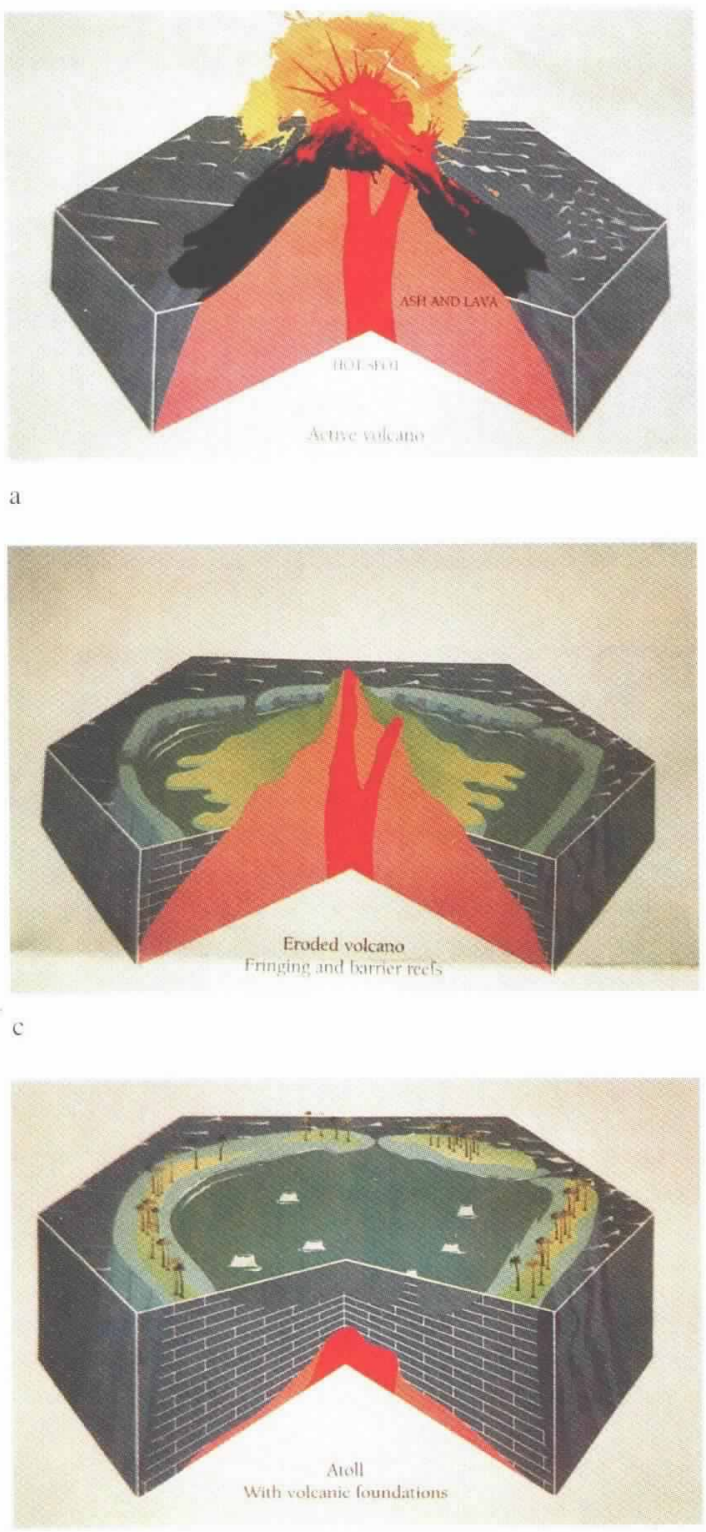

ecosystems and play a significant role in helping maintain the resilience, stability, and accelerated coral reef recovery following natural and anthropogenic disturbances. Coralline algae are extremely robust and help cement large chunks of coral and other reef remains together to form very hard and wave-resistant reef structures. Fishes, sea urchins, and other herbivores graze down growths of fleshy algae or seaweeds, allowing both reefbuilding corals and coralline algae to flourish and maintain reef growth and overall health.

Diversity of reef-building corals and other reef organisms tends to diminish in an east to west direction across the tropical latitudes of the Indian Ocean; however, the Red Sea supports higher levels of species diversity than any Eastern Indian Ocean region. Figure 3 illustrates the global distribution of reef-building coral genera, whereas Figure 4 illustrates the global distribution of $>6,000$ coral reefs recorded to date in "ReefBase," the

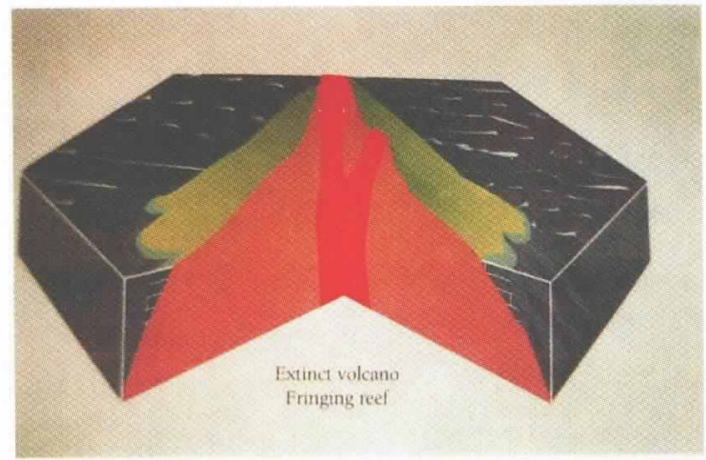

b

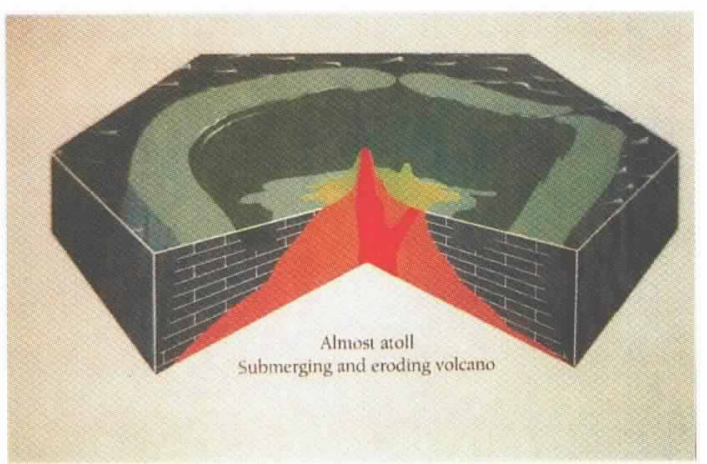

d

Fig. I: Illustration of the process by which volcanic eruption $(\boldsymbol{a})$, followed by periods of gradual subsidence of volcanic isand $(\boldsymbol{b})$, can result in the evolution of fringing reefs $(\boldsymbol{c})$, to barrier reefs $(\boldsymbol{d})$ and atolls $(\boldsymbol{e})$.

global database on coral reefs being compiled at the International Center for Living Aquatic Resources Management in the Philippines. Productive fisheries also occur in the southern Red Sea (Fouda, 1995). Mangroves and seagrasses associated with coral reefs are widely distributed throughout the region, and seagrasses attain their greatest development in the Red Sea, attributed to wider and shallower shelves. An excellent recent review of the status of South Asian (Bangladesh, Chagos, India, Maldives, Pakistan, and Sri Lanka) coral reefs is White and Rajasuriya (1995). As with other coral reef regions dominated by continental coastlines, coral reef growth in South Asia is inhibited by massive freshwater and sediment inputs from large rivers and by cold upwelling in the north.

Southeast Asia is the center of biodiversity for the reefs of the world (Fig. 3) and contains about one-third of the world's coral reefs. Recent re-

\section{Southeast Asia is}

the center of biodi-

versity for the reefs

of the world and con-

tains about one-third

of the world's cora reefs. 

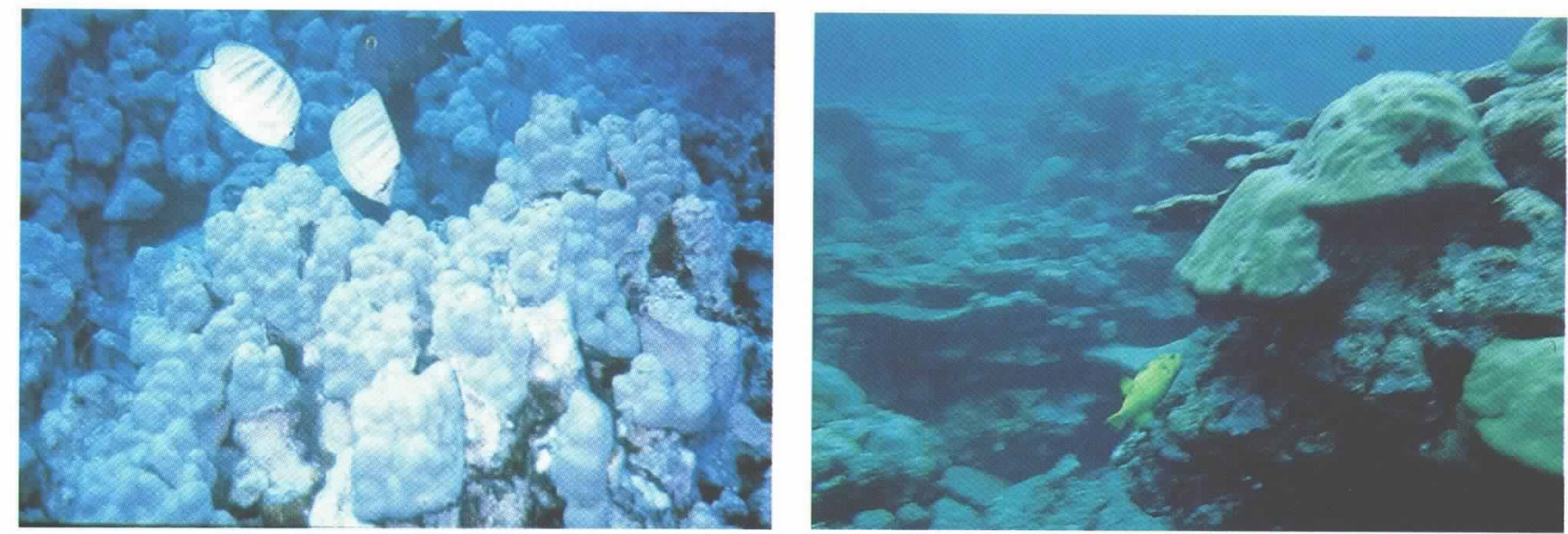

a

b
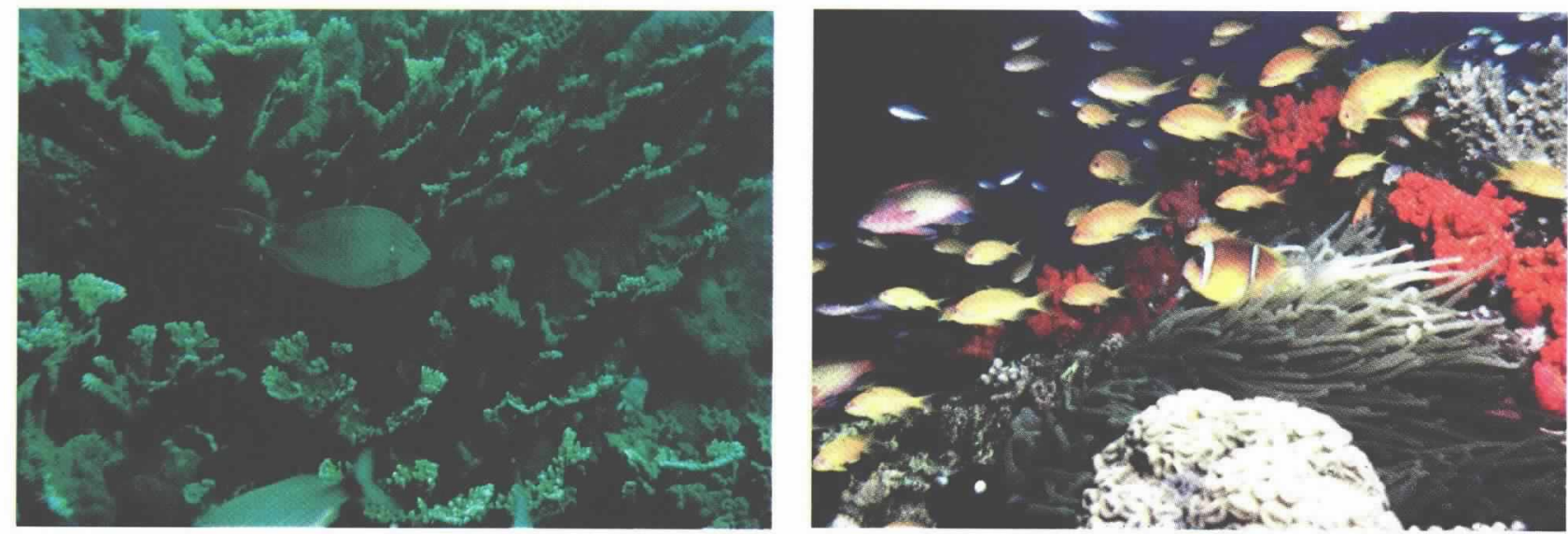

d

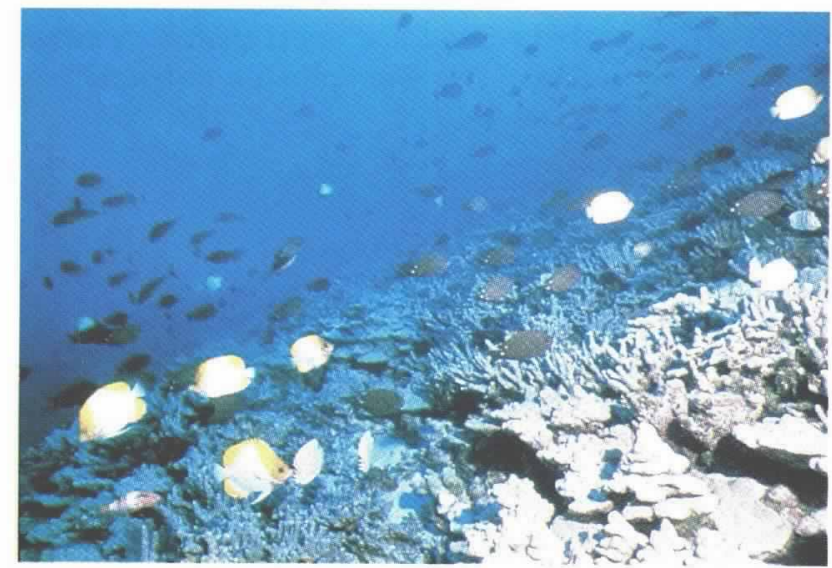

e

Fig. 2: Examples of healthy coral reefs. (a) Kaho'olawe Island, Hawaii, USA (R. Kosaki). (b) Fagatele Bay National Marine Sanctuary, American Samoa, USA (H. Hudson). (c) Florida Keys National Marine Sanctuary, USA (H. Hudson). (d) Red Sea Marine Peace Park, Aqaba, Jordan (Mohamed Al-Momany). (e) Kona, Hawaii, USA (R. Kosaki).

views of the status of these reefs are found in McManus (1988) and anonymous (1995). Although surprisingly little is known about the numbers and distributions of most coral reef species, existing information indicates that Southeast Asia tends to have perhaps four to six times as many species in a given group (fish, corals, gastropods, bivalves) as the Caribbean and peripheral areas of the $\mathrm{Pa}$ - cific. For example, there are $\sim 48-70$ species of reef-building corals (depending on definitions) in the Caribbean, whereas in the Philippines there are $>90$ genera and $>400$ species. The diversity difference with East Africa and the Red Sea tends to be much less with Southeast Asia having only perhaps two to four times more species in a given group (Fig. 3). The Pacific region is so large, that 
most islands and reefs have never been visited by reef scientists. However, some tropical Pacific coral reef ecosystems are documented to contain $>1,300$ species of reef fishes (Kulbicki, 1992). Most coral reef studies have taken place near the 20 urban centers in the region (Smith 1995; Maragos and Holthus 1996).

The incredible diversity of organisms found associated with coral reefs also holds great promise for improving the quality of life for the human species. In the ever evolving field of biotechnology, chemical extracts derived from coral reef associated sponges and tunicates have been indicated to have potent anti-viral activity (NSTC, 1995). In addition, several sponge and nudibranch species found in coral reef ecosystems are capable of producing terpenes, a broad class of aromatic compounds used in solvents and perfumes and known to deter feeding by fish. Extracts derived from these same species have also demonstrated powerful insecticidal activity against grasshoppers and the tobacco hornworm (Cardellina, 1986). Porites and other species of New Caledonian reef coral have been used as bone grafts for people requiring maxillofacial and cranial surgery (Roux et al., 1988), and pieces of Gorgonian corals have also been used successfully (Lopez et al., 1989).

Not only are coral reef ecosystems an important resource in terms of their biological diversity and productivity, they are also the foundations of coastal protection, tourism, and subsistence economies and in many areas serve as focal points for cultural and community heritage. On the Great Barrier Reef, the visitor and resort industries annually gross over one billion a year in revenues. Using the United States as an example:

- In all U.S. coral reef areas, reefs are the basis for most tourism and most tourism development, accounting for billions of dollars in construction and sales annually. The Florida Keys reef tract is a primary attraction that draws an estimated 2 million tourists to the Keys, with a direct revenue impact approaching $\$ 800$ million (1990 figures);

- In American Samoa, coral reefs play a central role in all aspects of traditional culture, from land tenure to diet. Reefs account for $>50 \%$ of all fish caught locally; and

- For Guam and the Northern Mariana Islands, which lie in the track of "Typhoon Alley," reefs provide protection from extraordinary ocean action that would otherwise devastate whole communities and result in the expenditure of tens of billions of dollars in federal disaster assistance.

The transboundary influences both to and from coral reef ecosystems are not limited by political boundaries. Just as ocean currents are potential carriers of pollutants from one country to another, larval and adult life stages of coral reef organisms may travel from reef to reef across national bor-

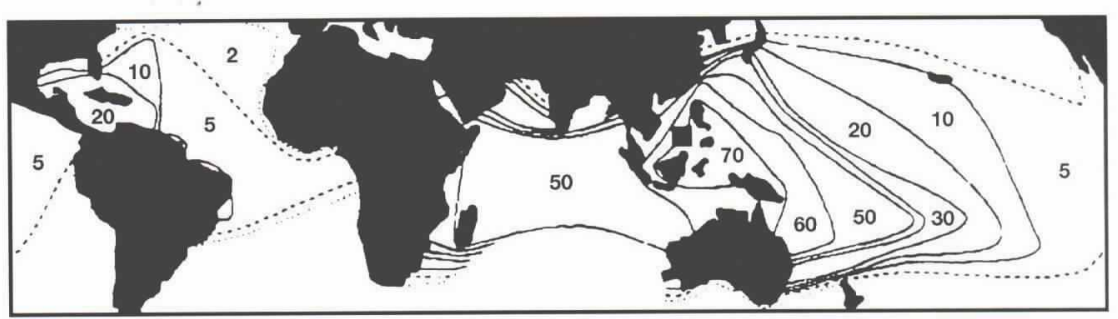

Fig. 3: Map of the diversity and global distribution of reef building coral genera, illustrating the highest number of genera to be in eastern Southeast Asia (re-drawn from Veron, 1993).

ders. Hence a global perspective is important for all nations to take when addressing threats to coral reefs.

\section{Threats to Coral Reefs}

Coral reefs first formed along the original continent of Pangaea 300 million years ago, even before the continents themselves began to drift apart and move to their present configurations (Veron, 1986). The resilience of modern coral reefs is manifested by their continuous survival and expansion during the Pleistocene, a period of several major rises and fall of sea level. In fact, virtually all of the major coral reefs observed today grew $\sim 100 \mathrm{~m}$ during the past 10,000 years, as sea level began to rise at the end of the last glacial age. Thus for over millions of years, coral reefs have shown remarkable power of resiliency and adaptations to environmental changes. However, the ability of coral reef ecosystems to exist in balanced harmony with other naturally occurring competing/limiting physicochemical and biological agents has been severely challenged in the last several decades by the dramatically increased negative

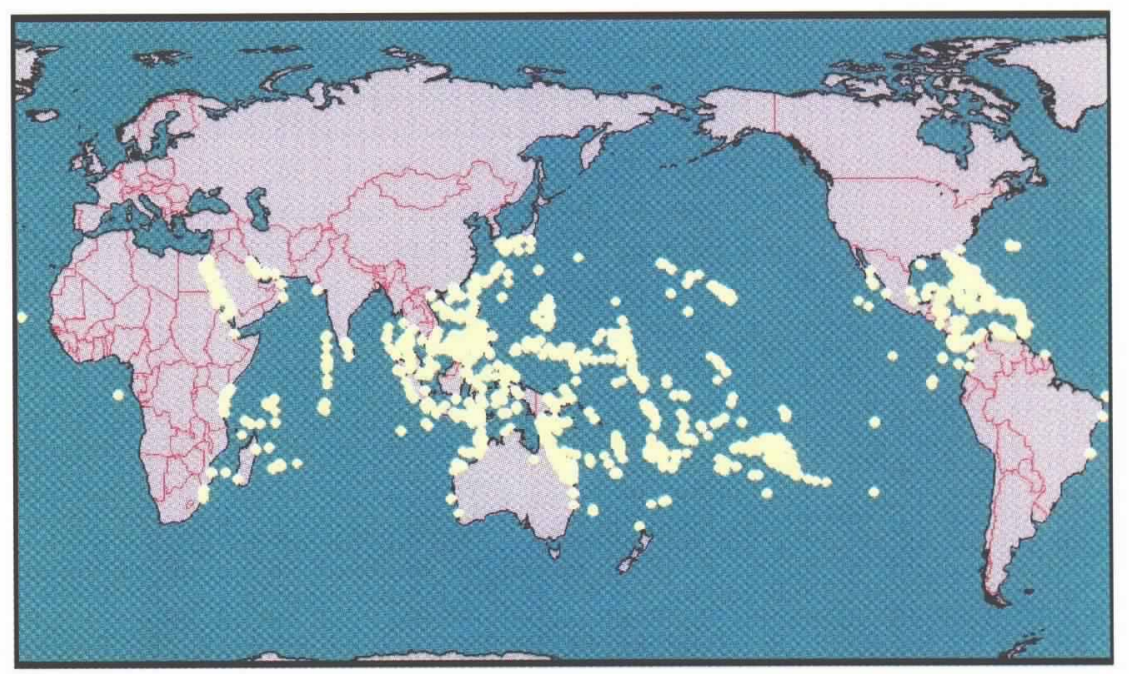

Fig. 4: Map of the global distribution of $>6,000$ coral reefs recorded to date in "ReefBase," the global database on coral reefs being compiled at the International Center for Living Aquatic Resources Management in the Philippines. 
and synergistic impacts from poorly managed anthropogenic activities.

Natural and biogenic erosion of the carbonate rock structure of coral reefs is constantly occurring from wave action. currents, and the feeding and boring activities of fish, algae, mollusks, and worms. In long-living reefs, carbonate accretion usually outpaces coral reef erosion, resulting in net reef growth. However, a variety of natural factors may prevent net reef growth, especially prolonged periods of adverse conditions, such as cold and extreme high temperatures, storm activity, earthquakes, lava flows or excessive sea level rise or fall such as the sea level functions occurring during the glacial and interglacial ages. The advent of anthropogenic stresses or threats to coral reefs can also disrupt coral reef survival and growth, resulting in net erosion and deterioration of reef structures. The synergistic effects of natural and anthropogenic disturbances may exacerbate adverse effects to coral reefs.

The major documented impacts to coral reefs are occurring near urban areas, and the reasons are simple. Lands are cleared for housing, agriculture. livestock grazing. and other development, eroding soils and resulting in sedimentation and runoff to coral reefs. Coastal construction for harbors, shore protection, causeways. channels, airfields, roads, and building materials are also located near urban centers. Sewage and industrial discharges are also concentrated, and edible reef species are more heavily harvested and depleted. Huge tracts of mangroves have been converted to shrimp ponds. Popular recreational reef areas are trampled by waders, smashed by anchors, and harvested by shell and coral collectors. It should therefore be of no surprise that most reef destruction and damage is chronic and occurring in such centers. Furthermore, most research facilities, colleges, and universities in the tropics are also located in population centers. Hence the damage and destruction is also documented primarily by scientists living in such centers, and their research is supported by the political will and financial support that are also more concentrated in these locations. Non-point source pollution, eutrophication, alien species from aquaculture schemes, oil spills, and ship groundings also occur more often near population centers. Many critically important reefs are now in need of intervention to arrest further degradation and to apply restrictive measures. However, reef restoration is expensive, and there are few proven technologies available (Maragos, 1992).

Coral reefs are also being degraded at an alarming rate in more remote areas, although documentation and evidence is less extensive. Destructive fishing practices such as the use of dynamite, poisons. and illegal gear is often conducted beyond the watchful eye of concerned governments and residents. Foreign fishing boats illegally land on sparsely inhabited or uninhabited atolls and coral islands to poach rare species of giant clams, which are thought by some Asians to have aphrodisiacal properties. Many sea turtles are also illegally harvested for their shell to fuel the bekko jewelry trade in the Asian markets. Other sea turtles are harvested for their meat and eggs for subsistence or sale, particularly at the fewer remaining remote resting beaches. Shark fin, pearl shell, trochus, conch, and coconut crabs are also heavily depleted for commercial trade. Remote atolls and submerged shallow reefs attract more than their share of shipwrecks, oil spills, and groundings: many are tiny and nearly invisible beyond a few kilometers, and navigation charts in remote areas are not as accurate. The frequent occurrence of coral bleaching on many reefs in recent years and increased greenhouse gas emissions are leading many scientists to believe that global climate change may lead to further coastal degradation and damage to coral reefs from flooding, sea level rise, and increased incidence and intensity of storms. Although linking a "greenhouse" effect to coral bleaching is controversial, recent remote sensing studies of sea surface temperatures by the U.S. National Oceanic and Atmospheric Administration (A. Strong. personal communication) and others (see Science 270, 919) seem to demonstrate correlations between elevated water temperature and recent bleaching events in Belize.

Photographic vignettes of many of the anthropogenic threats now degrading coral reefs on a worldwide basis are presented in Figure 5. Tables 1-4 present a compilation of the major threats to coral reef ecosystems around the world. The following sections are brief overviews of these threats, region by region.

\section{Atlantic and Caribbean}

Storms, floods, earthquakes, predation, and disease are the major natural disturbances to the Atlantic and Caribbean coral reefs, but recovery from major hurricanes in recent years has been unusually slow (Woodley, 1995). Significant impacts to coral reefs have resulted from white-band disease, which affects elkhorn coral, and from the mass mortality of the long-spined sea urchin Diadema antillarum (a grazing herbivore) in 1983, which led to excessive growths of benthic algae that competed for space against stony corals. Several episodes of coral bleaching since 1987 have led some scientists to believe the warm water temperatures and possibly increases in ultra-violet radiation triggered the responses (see above). Mass mortality of the Diadema, first seen off the Caribbean coast of Panama, has been attributed to a pathogen carried through the Panama Canal. Thus in both cases. there appears to be a strong link to the activities of humans (Woodley, 1995). Moreover, stress from other causes (see next paragraph) may make corals more susceptible to diseases or bleaching. 
Other anthropogenic impacts to coral reefs are much more closely linked to the very dense populations of humans that surround most of the coral reefs in the Gulf of Mexico and Caribbean. The principal threats include 1 ) runoff of sediment. nutrients, freshwater. and other pollutants caused by deforestation. farming, urbanization: 2 ) coastal construction and industrial activities that contribute comparable discharges and populations: 3) overfishing and destructive fishing techniques that have reduced populations of key predators and herbivores on reefs shifting the ecological balance: 4) mining of corals; and 5) overuse of many reefs by tourists and recreationists including damage from souvenir collection. boat-anchoring, and diver contact. Depletion of herbivorous fish from Jamaican reefs following the mass die off of $D i$ adema has had devastating impacts on coral reefs and demonstrates the catastrophic damage that can result when chronic anthropogenic impacts are superimposed on natural disturbances such as hurricanes (Hughes. 1994: Woodley, 1995). Recent polls of observers across the Caribbean reported coral reef and associated fisheries degradation in 14 of 22 countries by Rogers (1985) and 8 of 13 by Smith and Ogden (1993).

\section{Middle East Seas and East Africa}

The principal threats to coral reefs in the western Indian Ocean/East Africa region include 1) pollution from land-based activities; 2) pollution from maritime transport, especially oil pollution: 3) exploitation of living resources: 4 ) coral and sand mining for construction purposes: 5) dredging and filling operations; 6) tourism-related activities: and 7) natural disasters, especially hurricanes, which cause excessive flooding, silt deposition. and wave damage (Fouda, 1995). In the Middle-Eastern Seas, the major threats to reefs stem from 1) urbanization and tourism, 2) oil exploitation and transport, and 3) industrial pollution and sewage discharges. Population growth and tourism is increasing throughout the region. Degradation of coral reefs is also occurring from heavy souvenir collection (Fouda, 1995). There is also increasing evidence of increased damage to reefs from predation by sea urchins and crown-ofthorns starfish (Glynn 1993: Salm 1993; Fouda 1995). Other natural disturbances to reefs result from temperature extremes, bioerosion, flooding and silt discharges, and wave turbulence.

\section{South Asictn Region}

Threats to coral reefs in the South Asia region include 1) military activities and coastal construction (Diego Garcia in Chagos), 2) heavy exploitation of all salable reef resources (Indian mainland), 3) various types of pollution including oil pollution and industrial discharges (Gulf of Mannar, Palk Bay), 4) coral mining (India. Sri Lanka), and 5) sedimentation (most mainland fringing reefs). Souvenir collection. heavy net fishing. and coral rock mining are widely practiced in the Maldives. and tourism impacts are on the rise including coastal construction. Most coral reefs in Sri Lanka have been severely degraded by human-induced damage and crown-of-thorns starfish infestations. Major anthropogenic stresses include sedimentation from soil erosion. coral mining. oil pollution, destructive fishing practices, overtishing, and overuse of reefs in tourism areas (White and Rajasuriya 1995).

\section{Solutheast AsiulEast Asia}

The threats to reefs in this area have been summarized by Gomez (1980). Yap and Gomez (1985). McManus (1988). and others. Most of the perturbations and stresses described elsewhere in this paper are found here in great frequency. Coastlines of Vietnam, southern China, the Philippines, the Sabah region of Malaysia, and much of Indonesia are packed with rapidly growing populations of coastal fishers and associated villagers. Because fringing reefs are often easily accessible and can be harvested with very little initial capital. they generally tend to support large number of very poor fishers and gathers. The range of vertebrates. invertebrates, and plants being harvested is large and growing. such that in Bolinao, Philippines. $>350$ species appear in the markets each year (McManus et al., 1992). The markets tend to have minimal or no ice. as is often true of boats delivering fish to sell. and a substantial amount of fish and invertebrates are lost too spoilage (Santos 1988: McManus et al., 1992). Where they existed historically, traditional systems of fishing and gathering restrictions have become revised. modified by western concepts of land ownership, made complex and dynamic, or abandoned entirely (Lopez 1985; Ferrer 1991: McManus et al., 1992). In many areas, reef shorelines have been settled by migrants from various areas, such that fishers constitute a mixture of cultural groups speaking four or five languages in a single municipality (McManus and Chua 1990: McManus et cil., 1992). This may lead to difficulty in attempts to conduct local coral reef awareness programs.

All of this tends to heighten feelings of desperation in resource use. and a trend toward increasing acceptance of fishing gears that are illegal, culturally unacceptable, and even dangerous to the users. This condition is known as "Malthusian overfishing" hecause of its relationship to the problem of diminishing resource availability in the face of rapid economic growth as identified by Thomas Malthus in the 18th century (Pauly et al., 1989; Pauly 1990; McManus et al., 1992: McManus 1996). Problems such as blast fishing. cyanide tishing, and the use of dangerous air compressors by deep-diving speartishers are becoming increasingly common throughout the more crowded coasts of the region. Additionally, muro-ami fishing. in which tens or hundreds of people drive fish into nets by bouncing weights at the ends of ropes on

\section{Depletion of herbiv-}

orous fish from

Jamaican reefs fol-

lowing the mass die

off of Diadema has

had devastating

impacts on coral

reefs and demon-

strates the cata-

strophic damage that

can result when

chronic anthropogenic

impacts are superim.

posed on natural dis-

turbances such as

hurricanes. 


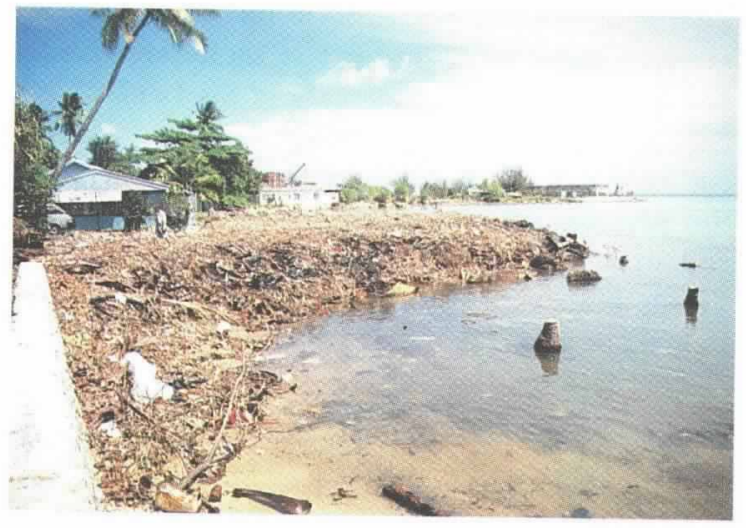

a

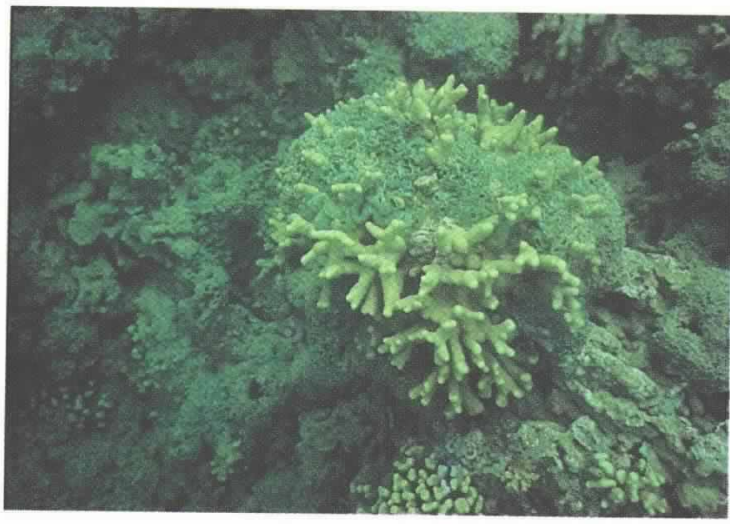

$\mathrm{c}$

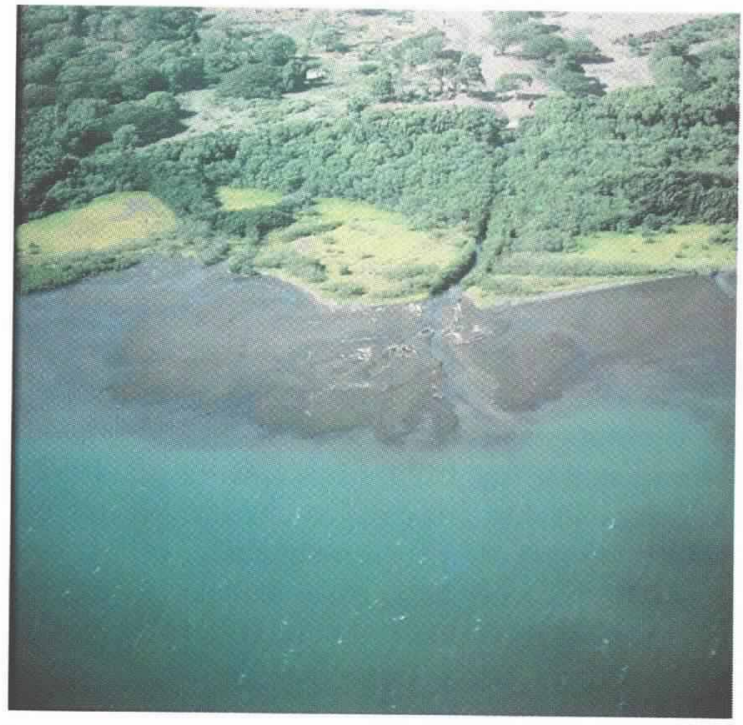

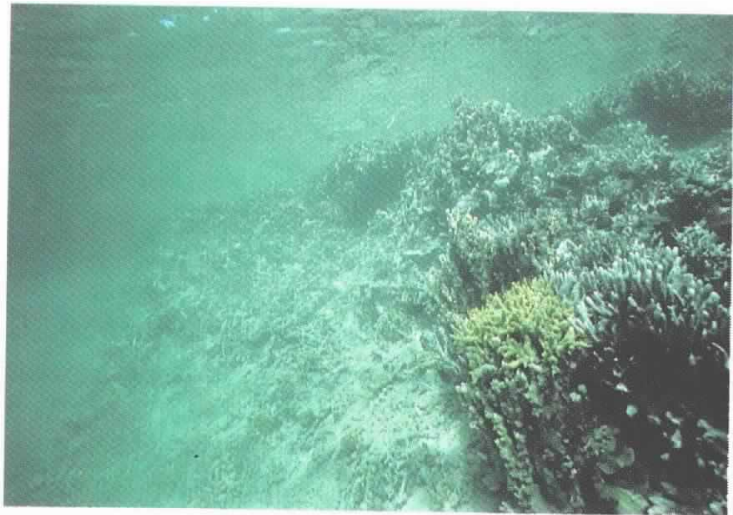

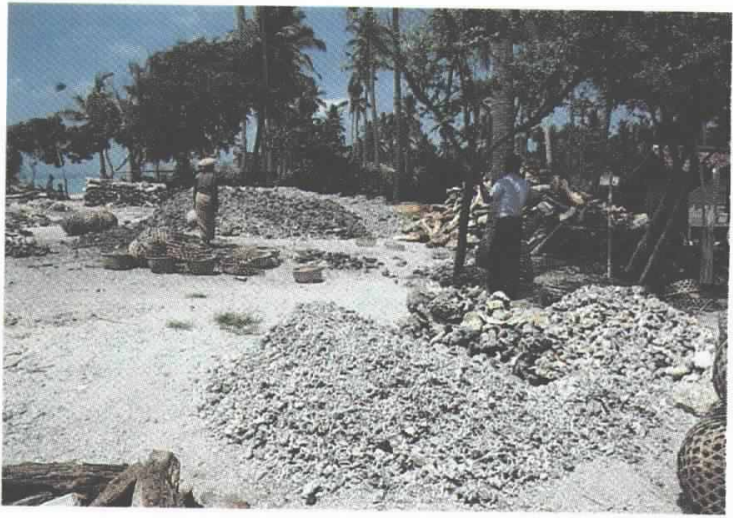

d

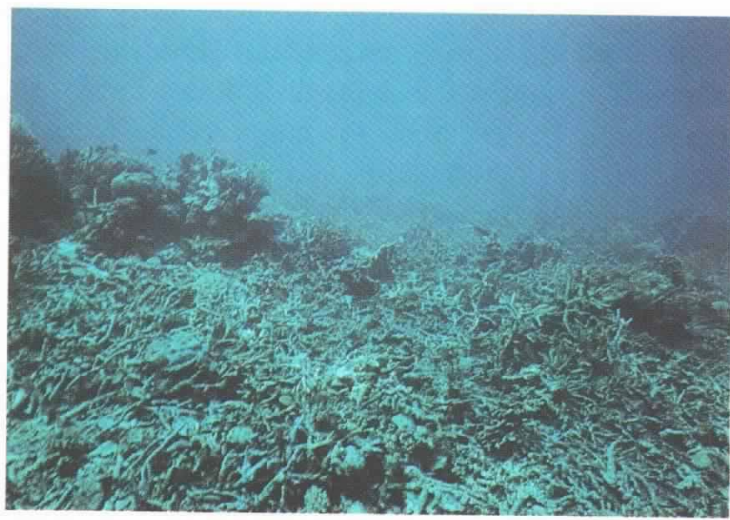

f

Fig. 5: Photographic vignettes of many of the anthropogenic threats now degrading coral reefs on a worldwide basis (All credits to J. Maragos, except $5 l$ to S. Frisk). (a) Refuse disposal on urban atolls and reefs in Tawara, Kiribati. (b) Results of live coral being dredged in Pohnpei, Federated States of Micronesia can be seen of the left of this photograph next to live coral on the right. (c) Nutrients from a secondary treatment lagoon outfall stimulate the growth of the bottom algae Dictyosphaesia, which is seen here growing up and over live coral colonies of the endemic Porites compressa in Kaneohe Bay, Hawaii, USA. (d) Villagers in Bali, Indonesia drying out piles of coral that was later burned in kilns to convert the coral carbanate to lime (calcium oxide). (e) A delta of sediment overlaying coral habitats is evidence of the enormous sediment discharges from poor land management (in this case pineapple and sugarcane agricultural practices and overgrazing of steep slopes by goats, sheep, and deer in Molokai, Hawaii, USA). ( $f$ ) Staghorn coral beds completely razed by persistent use of explosives for fishing in Ujung Pandang reef in 


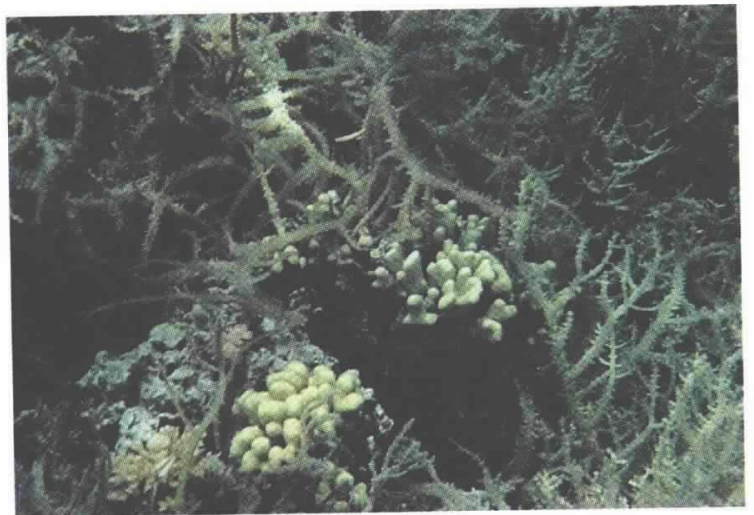

g
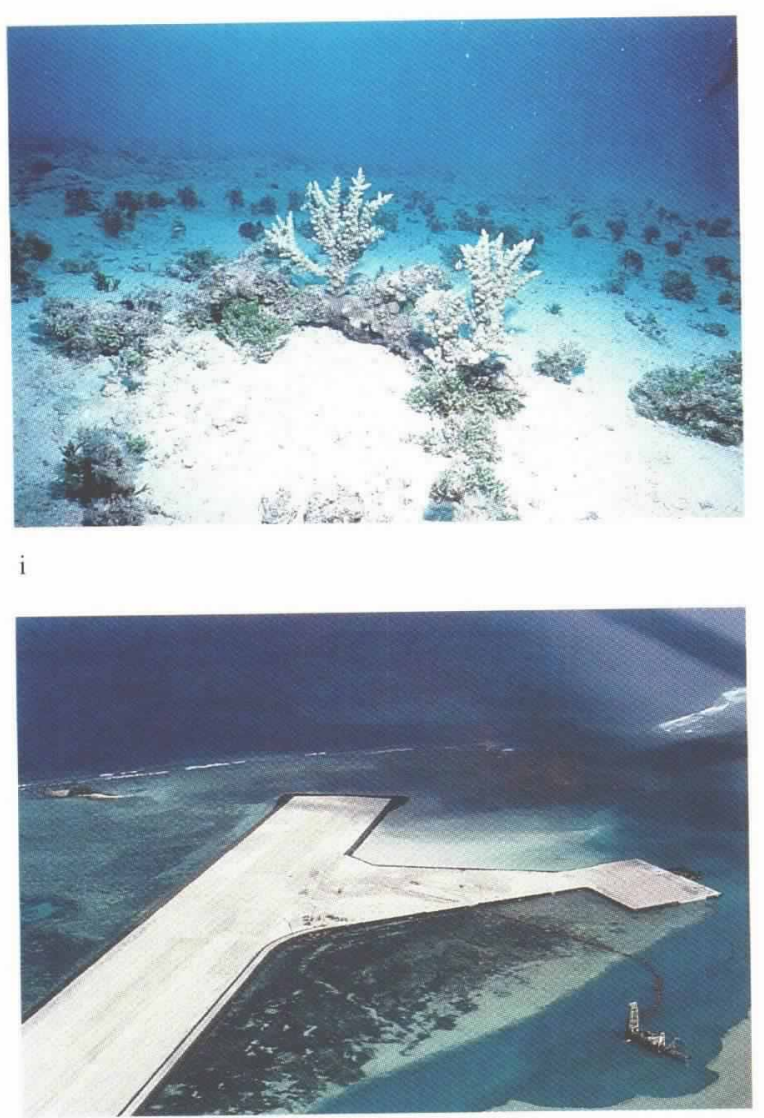

k

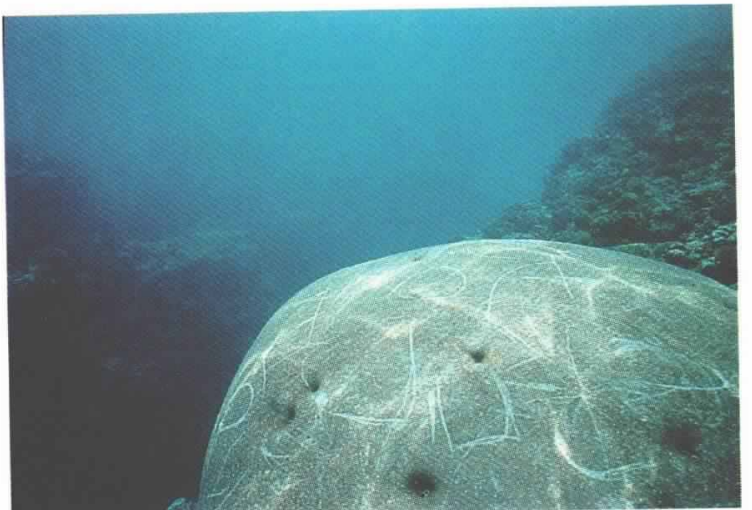

$\mathrm{h}$
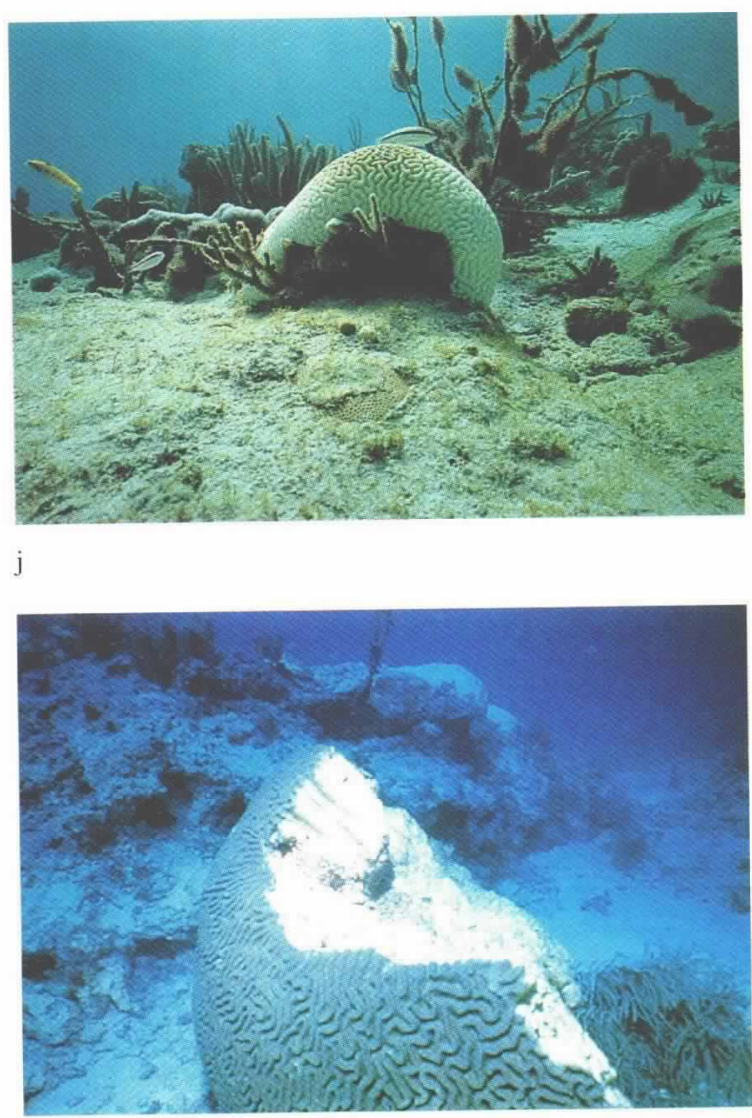

Indonesia. (g) Alien mariculture species (such as this red algae Eucheuma introduced to Hawaii from the Philippines) may cause ecological nightmares as they spread through and overgrow coral reefs. (h) Overuse and defacing of coral reefs at tourism sites as seen in Efate, Vanuatu, are the result of lack of education and awareness. $(i)$ The unprecedented impacts to coral reefs in the 1940s and 1950s from nuclear testing can still be seen in this 1986 photograph in the bottom of Bravo Crater at Bikini in the Marshall Islands. (j) Coral bleaching, such as seen in this brain coral at St. John, U.S. Virgin Islands, is thought to be caused by elevated temperature and may be more lethal in combination with other anthropogenic stressors. (k) Construction impacts, such as this airfield construction in Okat, Kosrae Island, Federated States of Micronesia, can destroy enormous areas of coral reef. (l) Ship groundings, such as seen by the result of a collision on a 100-yr-old brain coral in the Florida Keys, can also be extremely harmful to coral reefs.

coralline substrates, is a problem in the Philippines and adjacent waters (McManus 1996).

Fringing reefs are often adjacent to lands formed from raised, ancient reefs. This land is highly porous, such that groundwater flows often virtually unimpeded through interlinked caves. This lack of filtration means that waste materials from the crowded coastal villages, even when de-
Many, if not most,

reefs next to coastal villages are becoming increasingly overgrown with algae, which interferes with coral growth and inhibits the settlement of new corals. 


\begin{tabular}{|c|c|c|c|}
\hline Government & Typess of Reefs & Threats to Reefs & $\begin{array}{c}\text { Number of } \\
\text { Protected } \\
\text { Reefs }\end{array}$ \\
\hline Anguilla & Fringing. barrier, comm. & A. D, I, O & 1 \\
\hline Antigua \& Barbuda & Fringing, barricr. comm. & A. D, O, R, V, 1,2 & I \\
\hline Bahamas & Fringing, barrier, comm., atoll & A, D, O, R, 1, 2, 3, 4 & 5 \\
\hline Barbados & Fringing, comm., barrier & C. D, G, P, S, T, 1.4 & 1 \\
\hline Belize & Fringing, large barrier, comm. 3 atoll & A, C. O. R, S. T. U, 1,4 & 2 \\
\hline Bermuda & Fringing, barrier & A. C, D, P. O, T, V, I, 2, 4 & 2 \\
\hline Brazil & Cont. fringing. comm. atoll & D, I, R, S, T, LI, 1, 2,3.4 & 2 \\
\hline British Virgins & Comm., fringing, barrier coral & A. C. D. H. I. M, O. P. S. U. V & 1 \\
\hline Caymans & Coral, fringing, lagoon & A, D, M, O, P, R, S, T, U, V, I, 4 & 24 \\
\hline E. Columbia & $\begin{array}{l}\text { Several comm.. cont. fringing. attolls, } \\
\text { barrier }\end{array}$ & A. C. E, G. H, O. P. R, S, T, V & 2 \\
\hline E. Costa Ricat & Comm., fringing & C, H, O, P, R, S, T, U, 3, 4 & 2 \\
\hline Cuba & Comm., fringing, barrier, atoll & C. D. I. M. R. V & 1 \\
\hline Dominica & Comm., fringing & $\mathrm{H}, \mathrm{I}, \mathrm{O}, \mathrm{R}, \mathrm{S}, \mathrm{I}$ & 0 \\
\hline Dominican Republic & Comm.. fringing. barruer & D. E. G. H, I. M. O. P. R, S. T. U. I & 2 \\
\hline Grenada & Comm., fringing. barrier & C, D. G. H, O, S. U, I, 2 & 1 \\
\hline Guadeloupe & Comm., fringing, barrier & C. D. G, H. I, M, O, P, R, S, T, V, I. 2 & 0 \\
\hline Haiti & Comm.. fringing, barrier & I. O.R.S. 4 & 0 \\
\hline Honduras & Comm., fringing, barrier & A, C, P, S, T. I & 0 \\
\hline Jamaica & Comm. fringing, barrier & A. D. F, O, P. R, S, T, U, V, 1.2,3,4 & 2 \\
\hline Martinique & Comm., fringing. barrier & C, I, O, P. R, S. T, 1, 3, 4 & () \\
\hline Mexico & Cont. comm. fringing, harrier. atoll & D. H, I, O. P, R, S. T, U, V, I, 4 & 4 \\
\hline Monterrat \& St. Kitts-Nervis & Comm.. fringing. barricr & M. O.R. T. 1 & 0 \\
\hline Netherlands Antilles & Comm., fringing, barrier & A, C, D. E, H. I, M, O, P, R, S, T, U. V, $1,3,4$ & 2 \\
\hline Nicaragua & Comm., fringing, barrier & $\mathrm{S}$ & 0 \\
\hline E. Panama & Comm., fringing & C. F. G, H. O.P.S, V. $2,3,4$ & 1 \\
\hline Puerto Rico & Subm. comm., fringing, burrier & A, B, C. D, E, H, I, M, O, P, R, S, T, V, I, 3, 4 & 0 \\
\hline St. Lucia & Comm.. fringing. patch & A.C. D. E, M, O, R. T, U. 1, 3.4 & 1 \\
\hline St. Martin \& St. Barthelemy & Comm.. fringing, barrier & M, P. R, U & 1 \\
\hline St. Vincint & Comm., fringing. barrier & $H, P, R$ & 0 \\
\hline Trinidad \& Tobago & Comm.. fringing, patch, barrier & A. C. O, R, S, U, $1,2,3$ & 1 \\
\hline Turks \& Caicos & Comm., fringing. barrier & C, D, H, M, O, P. R, S. T, V & 0 \\
\hline U.S.A. Atlantic/Gulf Coast & $\begin{array}{l}\text { Cont.. comm.. patch. bank/barrier \& } \\
\text { one pseudo-atoll }\end{array}$ & A. C. D. E, G. H. I, O. P. R. T. V. I, 2, 3, 4 & 6 \\
\hline U.S. Virgins & Comm., fringing, barrier & A. C, E, H. I, M, O, P. R, S, T, U. V. 1. 2.3.4 & 2 \\
\hline Venezuela & Cont., comm., fringing, barrier, atolls & H, I, O, P. S, T, V, 3, 4 & 3 \\
\hline West Africa & Cont. communities & No information & $?$ \\
\hline
\end{tabular}

Tables 1-4: Summary information on the coral reef of the world including reef types, natural and anthropogenic stresses, and number of protected areas, subdivided into four regions (After UNEP/IUCN 1988 and various other sources).

Explanation of reef terms: comm., community, nonstructural reefs, only communities present: deep, submerged or deep shelf reefs: fringing, tringng reefs around volcanic coasts; coral, fringing reefs around coral islands: barrier, barrier reefs off volcanic coasts or islands; atoll, atoll reef; cont., continental, bank reefs off continental coasts; other, reefs other than above.

Explanation of symbols for Natural Threats to reefs: 1, troptal cyclones, storms: 2, disease; 3. coral bleaching/El Nino; 4, sea urchin die off: 5 , starfish predation: 6. flooding/heavy rains; 7. cold temperatures: 8 . low tides: 9, heal'y wave action: 10, voleanic eruptions: 11. earthquakes: 12. tsunamis: 13. emergence; 14, submergence (subm.).

Explanation of symbols for Anthropogenic Threats to coral reefs: A. anchor damage: B. bombing/military activity; C. coastal construction; D. destructive fishing: $\mathrm{E}$, thermal pollution: F. flooding; $\mathrm{G}$, agricultural runoff: H, hazardous/solid/mining waste: I, industrial pollution; $M$, mining of coral; $O$, overharvesting and overfishing; $P$. pollution from nutrients and sewage; $R$. poaching or depletion of rare reef species: S. soil erosion and sedimentation from fire. overgazing, deforestation. land clearing. etc.: T. tourism and resorts: U. overuse/trampling; V, vessel groundings and oil spills.

dredging, mining, and

other sources cuts

back on coral growth

posited on land. generally have a strong effect on adjacent reefs. Many, if not most, reefs next to coastal villages are becoming increasingly overgrown with algae, which interferes with coral growth and inhibits the settlement of new corals. Plastic bags, discarded by the millions, snag around corals and mangrove shoots, killing them. Sea turtles ingest the bags, mistaking them for jellyfish, and they too die. Villagers collect turtle eggs and actively hunt turtles, dugongs, and other large vertebrates for food. Buyers from China and Japan op- erating in the Philippines often initiate harvesting of sea cucumbers, sea urchins, or sharkfins, which last only a few months before local stocks become depleted, causing the buyers to move on and stimulate depletion of additional reefs.

Pollution from cities tends to be more varied and have more widespread effects. Oil commonly inundates reefs, particularly those near transfer facilities (Gomez 1978; Bilal and Kuhnhold 1980). Excessive sedimentation from deforestation. construction, dredging. mining, and other sources cuts back on

communities. 
Table 2

A compilation of the major threats to coral reef ecosystems in West Australia and South Asia

\begin{tabular}{|c|c|c|c|}
\hline Government & Types of Recefs & Threats to Reefis & $\begin{array}{c}\text { Number of } \\
\text { Protected } \\
\text { Reets }\end{array}$ \\
\hline W. Australia & Comm., fringing, cont., harrier, atolls & A.C.D. O, R. T. V. 1.5.11 & 3 \\
\hline Bangladesh & Comm.. submerged & D. I.P.R.T & () \\
\hline Burma & Fringing. cont., comm. & $?$ & () \\
\hline Brunei & 3 Communities. subm., fringing, coral & $?$ & 0 \\
\hline Chagos & Subm.. 5 atolls & C. V. $5.11,13$ & () \\
\hline Comoros & Comm., fringing. barrier & D. M, O, R. S, U, 3, 5 & 1 \\
\hline India & Cont., fringing. patch. atolls barrier & D, G. I, M. P, R, S, T, V, 1, 5, 6 & 2 \\
\hline Indonesiia & All types of reefs & A, C, D, G, I, M, O. P. R. S. T, V. 3.5. 10 & 14 \\
\hline Kampuchea & Comm.. cont. & $?$ & 0 \\
\hline Malaysia & $\begin{array}{l}\text { Cont.. comm.. patches, coral, tringing. barrier. } \\
\text { atoll }\end{array}$ & D. G. H, M. O, P. R. S. T. V. 5,13 & 9 \\
\hline Maldiver & Atoll, coral & A.C. D. I. M. O. P. R. T. U. V., 5 & 0 \\
\hline Pakistan & Communities & & ) \\
\hline Philipines & All types of coral reefs & A, C. D, G. H. I, M, O, R. S, T, V. 1.5, mangroves & 16 \\
\hline Seychelles & Comm.. subm.. fringing, patch. coral, atoll & C. G. H. M. O.P. R. 2.5 & 10 \\
\hline Singapore & Comm., fringing, cont. & $A, C, R, V$ & 0 \\
\hline Sri Linka & Comm.. fringing. pattch, coral & A. D. G. M. O, R, T, 5,6 & 2 \\
\hline Thailand & Cont.. comm.. fringing. coral & A. C. D. G. H. I. M. O. P. R. 5.13 & 9 \\
\hline Vietnam & Cont., coral & & 0 \\
\hline
\end{tabular}

For explanation of terms. see Table 1.

coral growth and settlement and often results in the burial of coral communities, particularly small nonreef coral communities (Alino 1983). Construction threatens many reefs and is a leading cause of damage in Singapore (Newman and Chuan 1994) and Japan (Veron 1992). A study of corals in Japan has recently concluded that many species there may face local extinction because of abuses related to coastal development and the fact that replenishing stocks from the Philippines may diminish because of reef degradation there (Veron 1993).

\section{Pacific}

The most serious documented impacts to Pacific coral reefs are concentrated in the urban centers: 1 ) soil erosion and sedimentation off volcanic islands,

Table 3

A compilation of the major threats to coral reef ecosystems in East Africa and the Middle East

\begin{tabular}{|c|c|c|c|}
\hline Government & Types of Reets & Threats to Reefs & $\begin{array}{c}\text { Number of } \\
\text { Protected } \\
\text { Reefs }\end{array}$ \\
\hline Bahrain & Coral, fringing. patch. barrier, atolls"? & A, C, H, O, V, 5 & 0 \\
\hline Djibouti & Cont., fringing. patch & A.C. D. O, R, U. V & 5 \\
\hline Egypt & Fringing, comm., patch & A. D. H. O. T. U. V. 5 & 2 \\
\hline Ethiopia & Comm.. fringing. coral, patch & H. R. I & 0) \\
\hline Iran & Comm., fringing & V.H & 1 \\
\hline Israel & Fringing, patch, comm. & C. M. T. V. 13 & 1 \\
\hline Jordan & Fringing. patch, comm. & A.C.D.I. M. V. 5.13 & 1 \\
\hline Kenya & Cont. comm., fringing. coral, patch & D, G, I, R, U, V, 5 & 4 \\
\hline Kuwait & Comm., fringing, coral & A. H. 1, V. $5,7,13$ & 0 \\
\hline Madagascar & Cont. comm. fringing, barrier. subm. & D. O.R.S & 1 \\
\hline Mauritius & Coral, fringing, patch. barrier & A, C, D, G, M, O, P, R, S, T, 1,5 & 6 \\
\hline Morambique & Cont. fringing. comm. & D. G. H. I. T & 2 \\
\hline N. Y'emen & Comm. fringing, subm. & $?$ & ) \\
\hline Oman & Comm., patch, fringing & C. D. H. O.R.U. V. 7.8 & 0 \\
\hline Qiatar & Comm.. fringing. barrier?. atoll? & P. $V$ & 0 \\
\hline Reunion & Comm., coral, fringing, atolk subm. & D. G. H. O. P, R, S, U, 3 & 6 \\
\hline Saudi Arabia & Cont. fringing, atolls. harrier, coral. patch. comm. & C. D. H. I. O.P. R. U. V. 2.5 & 0 \\
\hline Somalia & Cont. comm., barricr, fringing. patch & C. M, P.S. V & 0 \\
\hline S. Africa & Comm. & C. U. V, 6 & 1 \\
\hline S. Yemen & Comm. & $\mathrm{V}$ & 0 \\
\hline Sudant & Comm. fringing. barrier. atoll & A. D. H. I. P. R. U. V. 5 & 1 \\
\hline 'Tanzania & Comm., fringing, coral, patch, cont., 1 atoll & D. P. R.S. U & 8 \\
\hline United Arab Emirates & Comm.. subm., patch & 7 & 0 \\
\hline
\end{tabular}

For explanation of terms. see Table I. 


\begin{tabular}{|c|c|c|c|}
\hline Government & Types of Reefs & Threats to Reefs & $\begin{array}{c}\text { Number of } \\
\text { Protected } \\
\text { Reefs }\end{array}$ \\
\hline American Samoa & 2 Comm., 5 fringe. 1 barrier, 2 atolls & C, D, F, I, O, P, R, S, V $1,6,3,13,5$ & 3 \\
\hline E. Australia & All types except atolls & A. C, D. F, G, P. R. S, T, U, 5, 6 & 12 \\
\hline Chile (Easter I.) & 2 Comm. & C. S, V, 1,4 & 0 \\
\hline China & Comm., subm., atoll, fringing. coral & C, M, O, R. V, 1 & 3 \\
\hline W. Columbia & Cont.. comm.. fringing & A, C, D, G, O, P, R, S, T & 2 \\
\hline Cooks & 7 Fringing, 1 barrier, 7 atolls & C, D, I, O, R, S, 1, 5 & 3 \\
\hline W. Costa Rica & Comm.. fringing & C. M, O, P. R. S. T, U. 3 & 10 \\
\hline Ecuador (Galapagos) & Comm., subm., fringing & $\mathrm{O}, \mathrm{R}, \mathrm{T}, 3$ & 4 \\
\hline Fed. St. Micronesia & Subm., 27 fringing, 2 barrier, 31 atolls & C, D, I, M, O, P, R, S, V, 5 & 2 \\
\hline Fiji & 13 Fringing, 22 barrier. 3 atolls & C. D, F, H, I, O, P, R, S, V, 5 & 0 \\
\hline French Polynesia & 12 Comm., 18 fringing, 10 barrier, 79 atolls & C, D, F, H, I, O, P, S, T, U, V, 1,6 & 2 \\
\hline Guam & Comm., fringing. 2 barrier & B, C. F, H, O, P, S, T, V, 1, 3, 5, 13 & 4 \\
\hline Hawaii \& other U.S. Is. & 14 Comm., 14 fringing, 2 barrier, 9 atolls & $\begin{array}{l}\text { A, C, D, E. F, H, I, O.P, S, T, U, V, 1, } \\
\quad 5,10,11,14\end{array}$ & 2 \\
\hline Hong Kong & Comm. & $\begin{array}{l}\text { A. B, C. E, F. G, H, I, O. P, R, S. T, V, } \\
\quad 1,5,12\end{array}$ & 0 \\
\hline Japan & Comm., coral, fringing & C, D, I, O, P, R, U, 7, 13 & 4 \\
\hline Kiribati & 3 Subm., 15 coral, 18 atolls & B. C. H, I, O, P, R, S, U, V, 1, 2, 3, 5,7 & 2 \\
\hline Marshalls & 5 Coral, 29 atolls & C, G, H, O, P, R, 3, 5, 6 & 0 \\
\hline Mexico & Cont., 1 comm. & B, C. E. H. I, O. P. R, V, 1,5 & 1 \\
\hline Nauru & 1 Coral & $\mathrm{V}, 9$ & 0 \\
\hline New Caledonia & 5 Fringing, 4 barrier. 5 atolls & F, H, I, O, R, S, V & 4 \\
\hline $\begin{array}{l}\text { New Zealand } \\
\text { (Kermadecs) }\end{array}$ & 15 Comm. & & 1 \\
\hline Niue & 1 Fringing & $\mathbf{U}, 1$ & 0 \\
\hline N. Marianas & 11 Comm., 11 fringing, 2 barrier & C, D, I, O, P, S, T, U, V, 1, 5,9,10 & 0 \\
\hline Palau & 2 Subm., 14 fringing, 1 barrier, 3 atoll, 5 coral & C, D, O, P, R, S, T, U, V, 5 & 3 \\
\hline W. Panama & Cont., comm. & A. C, F, O. P. S. V. 3 & 2 \\
\hline Papua New Guinea & Subm., comm., 24 fringing, 15 barrier, 41 atolls & C, D, F, I, P, R, S, V, 1, 5, 11 & 6 \\
\hline U.K. (Pitcaim) & 2 Comm.. 1 fringing, 2 atolls & 5.7 & 0 \\
\hline Solomons & Subm., comm., 16 fringing. 10 barrier. 3 atolls & C, D. I, P, R. S. V, 1, 3, 5, 11, 13 & 0 \\
\hline Taiwan & Comm.. fringing, subm.. atoll, coral, 3 atolls & A, C, D, O, R, T. U, V 1,5 & 2 \\
\hline Tokelaus & Comm.. fringing, subm.. atoll, coral, 3 atolls & C, O, R, V, 1.3.5.13 & 0 \\
\hline Tonga & 7 Comm., 37 coral \& fringing. 6 barrier & C. D, O, P, R, U, 1, 3, 5, 6, 13 & 6 \\
\hline Tuvalu & 1 Subm.. 3 coral, 4 atoll & C, P, R, V, 1 & 0 \\
\hline Vanuatu & 12 Comm., 42 fringing, 1 atol! & C, D, I, P, R, 1, 5, I3 & 2 \\
\hline Wallis \& Futuna & 2 Comm., subm., 3 fringing, 1 barrier & C, D, P, R, S & 0 \\
\hline W. Samoa & 5 Comm.. 7 fringing & C, D. I, O, P. R, S, 5 & 1 \\
\hline
\end{tabular}

For explanation of terms, see Table 1.

\section{On a global scale}

the most significant

threats to reefs are

associated with high-

density human popu-

lation living near

coral reefs.
2) coastal construction, 3) sewage and industrial discharges, 4) overfishing of subsistence resources and excessive commercial exploitation of other fisheries, 5) increased flooding and discharge of fertilizers and toxic chemicals, and 6) vast destructive fishing techniques, especially explosives. Military training and testing activities have also been conducted in the Line Islands, Marshall Islands, and French Polynesia (for nuclear weapons testing), with additional islands in Hawaii and elsewhere used for bombing. Tourism activities are increasing rapidly in many island groups resulting in overuse, trampling, anchor damage, and souvenir collections. On remote islands, primarily Asian fishing boats are illegally harvesting rare and depleted species, especially giant clams, sharks, and sea turtles. Overall, the status of most reefs in the region cannot be ascertained because of a paucity of information. It is likely that many coral reefs, especially on remote or uninhabited islands and atolls are still in an undistributed condition. Natural disturbances to Pacific reefs include typhoons and crown-of-thorns starfish outbreaks. El Nino southern oscillations may often result in warm water temperatures and coral bleaching events. Volcanic eruptions, earthquakes, subsidence, and emergence are other less frequent disturbances.

\section{What Can Be Done to "Turn the Tide?"}

On a global scale the most significant threats to reefs are associated with high-density human population living near coral reefs. Reef ecosystems in Southwest Asia, East Asia (Japan, China), South Asia (India, Sri Lanka), and the Caribbean appear especially degraded. In the Pacific, urban reefs appear to be declining near population centers. Human migration and population increase is the single most significant cause of reef degradation worldwide and is the basic cause for most of the impacts to coral reefs in urban centers. Elsewhere 
remote reefs are being preferentially degraded by illegal or destructive fishing and harvesting practices. Submerged reefs - the least understood of all major reef types - are probably being severely degraded by bottom trawling activities. Ship groundings and associated fuel and cargo spills are also becoming more serious threats. In recent years many actions have been taken to address the protection of coral reefs, but most of these actions have been taken on a piecemeal basis, one reef at a time.

The high human coastal densities and rapid population growth rates of many regions tend to call for a very tight coordination of village and governmental-level management planning and implementation, often referred to as co-management (Pomeroy and Williams 1994: McManus 1996). In regions having immediate problems with coastal construction impacts, the only practical solution in some cases has been to move an entire coral community, colony by colony, to a safer location (Newman and Chuan 1994).

Only a decade ago, it was not possible to speculate on the global status of coral reefs. However, much has happened recently to improve global awareness of the urgency to address threats to coral reef ecosystems. In 1985 Sue Wells and coworkers began to compile available information on coral reefs for all regions of the world as part of a United Nations Environment Program (UNEP) and IUCN sponsored initiative. The three volume set Coral Reefs of the World was published in 1988 and still serves as the most thorough global reference on coral reefs (UNEP/ IUCN, 1988). This effort is continuing in the form of ReefBase: the Global Database of Coral Reefs and their Resources, which will make data on the ecology, uses, abuses, and governance factors concerning the world's coral reefs available on CDROM in June, 1996. The ReefBase effort at the International Center for Living Aquatic Resources Management is supplemented by a project to digitize maps of coral reefs at the World Conservation Monitoring Center. The United Nations Conference on Environment and Development (UNCED) in Rio Di Janeiro in 1992 and Agenda 21 brought worldwide attention to the need for protection and monitoring of coral reef ecosystems. Recently at a 1993 conference on the Global Aspects of Coral Reefs, the concept for a "Year of the Reef" wats born. now targeted for 1997. The next (8th) International Coral Reef Symposium will be held in June 1996 in Panama and promises to devote considerable attention to reef management issues including a special session on the global status of coral reefs. A Global Task Team on Climate Change and the International Oceanographic Commission (IOC) have also published recommendations on coral reef monitoring procedures and are organizing a global network for monitoring coral reefs.
The Regional Seas Program of UNEP has also focused considerable attention to coral reef protection during the past decade with the establishment of regional approaches to control pollution and management of marine and coastal resources. In the tropical Pacific the South Pacific Regional Environment Program (SPREP) and in the Caribbean, the Caribbean Environmental Program (CEP) were established to provide a mechanism for culturally. economically, and politically diverse states and territories of each region to collectively address the protection of marine, coastal, and other environmental resources. Similar programs have been or are being established in the other Regional Seas regions of UNEP (e.g., the Coral African Regional Seas Program. etc.), and these promise to afford the appropriate degree of cooperation to lead to more effective management of coral reefs than would be possible only at the country or territorial level. At same time, additional emphasis is being placed on community level management or coral reefs. This last strategy has proven to be effective in enlisting the cooperation and support for effective management of marine protected areas by affected or nearby communities. These management initiatives are now progressing at community, national, and regional levels for coral reef management.

\section{The International Coral Reef Initiative}

The International Coral Reef Initiative (ICRI) is a partnership among nations and organizations seeking to implement chapter 17 of Agenda 21 of UNCED and other international conventionsand agreements. for the benefit of coral reefs and related ecosystems. The ICRI was founded by eight governments (Australia. France. Jamaica, Japan. Philippines. Sweden. United Kingdom, and United States) and was announced in December 1994 at the First Conference of the Parties of the Convention on Biological Diversity in December 1994. The eight original members later drafted a "Call to Action" to draft broad principles for further action. Since then, the ICRI has attracted the support of additional governments, UN organizations, multilateral development banks, environmental and development nongovernment organizations, the private sector, and "the research community." The first workshop for the ICRI was held in Dumaguete City. Philippines in June 1995 leading to the development of a "Framework for Action" based on the earlier "Call for Action." These two steps provide the basis for regional workshops that will define regional needs and priorities and catalyze the development of national coral reef initiatives. They also encourage UN agencies, convention bodies as well as multilateral and bilateral donors to incorporate ICRI into their programs and identify important roles for UNEP. International Oceanographic Commission (IOC), and the scientific community in monitor-
The International

Coral Reef Initiative

(ICRI) is a partner-

ship among nations

and organizations

seeking to implement

chapter 17 of

Agenda 21 of

UNCED and other

international conven-

tions-and agree-

ments, ... 
ing and addressing the serious global decline of coral reefs.

The Framework for Action is guided by several principles-full participation. and commitment by all parties; support actions with tangible positive effects on coral reefs and related ecosystems and human communities: managing human activities that degrade coral reefs; recognition of the diversity of cultures, traditions, and governance within nations and regions: integrated coastal management with emphasis on community participation; developing national capacity to conserve and sustainably use coral reefs; strategic research and monitoring programs; and taking advantage of the extensive body of international agreement and organizations that address issues related to coral reefs and associated ecosystems. The Framework for Action identifies activities in the following areas that address the need for conservation and sustainable use of coral reefs and related ecosystems-integrated coastal management: public awareness, education, and training: ratification of or accession to relevant international instruments: stakeholder participation at all levels; training policy makers and private sector decision makers in coral reef management: marine science and technology: environmental law, especially environmental impact assessment regulations: and assessing potential for microenterprise development and facilitating associated financing of it. The Framework for Action also emphasizes four substantive directions: Management. Capacity Building. Research and Monitoring, and Review. Specific actions are specified within each of these four areas of emphasis.

Regional workshops on the ICRI have been initiated including a South Pacific Regional Environment Program (SPREP) Workshop for the ICRI on 27 November to 1 December 1995. These workshops help to tailor the "Call to Action" and "Framework for Action" to fit the particular issues and needs within each region. For example at the SPREP workshop "beaches" were added to "mangroves" and "seagrass beds" as among the important associated coral reef ecosystems. The workshop also pointed out the "top down" approach of the ICRI to date with emphasis on government initiative and inadequate recognition and support for the participation of the scientific community. Notwithstanding the style of the development of the ICRI to date, it has the best hope to provide the needed international framework and guidance to help direct management of coral reefs more effectively at the International and Regional levels while giving more support to the need for National and Community level management. An important responsibility of the scientific community will be to evaluate the ICRI at the upcoming 8th International Coral Reef Symposium to be held in Panama. in June 1996. Also the support of ReefBase as the International Scientific database and GIS for coral reefs is warranted. In addition to
ReefBase. another major activity in support of the ICRI is the Global Coral Reef Monitoring Network. This activity will involve coral reef researchers around the world in coordinated monitoring of selected coral reefs. The program is expected to yield important insights into the causes of coral reef degradation and the responses of coral reefs to global change. The associated fieldwork is expected to be underway by 1997.

\section{The United States and Local Coral Reef Initiatives}

An outgrowth of the ICRI is the early development of national coral reef initiatives. The United States is developing an interagency CRI to create the base for a combined domestic and international effort aimed at the conservation and effective management of coral reef ecosystems (Crosby et al., 1995: Crosby and Maragos, 1995). The U.S. CRI is building on existing federal, state, territorial, commonwealth. and local partnerships through communication with relevant stake holders at all levels. Mechanisms for ongoing consultation among stakeholders have been initiated and are being expanded to take into account local needs, priorities, and opportunities in developing the U.S. CRI. Under the U.S. CRI, the National Oceanic and Atmospheric Administration (NOAA) is working in partnership at the federal, state, territory, and commonwealth level, seeking to integrate their operational management activities in an ecosystem-wide approach. increase monitoring, conduct assessments to provide better information for decision makers, provide education and outreach to increase public understanding. and undertake a more proactive effort in understanding and maintaining biodiversity of coral reef ecosystems. Efforts to achieve holistic management must consider not only the fish and the coral reef resources but also the ecological. social. economic, and political aspects that involve all stake holders. A key component of such a strategy would be promotion of healthy ecosystems by ensuring that economic development in the United States is managed in ways that maintain biodiversity and long-term productivity for sustained use of our coral reef ecosystems.

The primary objective of NOAA's involvement in the U.S. CRI is to foster innovative cross-disciplinary approaches to sustainable management and conservation of coral reef biodiversity and ecosystems through the development of cooperative relationships among the various stake holders. Perhaps the most important element within the U.S. CRI is support for community involvement in developing and implementing local and regional CRIs suited to those community needs and situations. For the U.S. and International CRIs to succeed in effectively conserving and managing coral reef ecosystems for long-term sustainable use, programs should essentially be based on local community involvement. To this end, the U.S. CRI (through support from 
NOAA and the Department of the Interior) sponsored Pacific and Caribbean regional workshops for U.S. states, territories, and commonwealths to assist the regions in working more closely together in promoting stewardship of U.S. coral reef ecosystems and in developing local CRIs. Scientists, government managers. nongovernmental organizations, and other interested residents have been actively planning local coral reef initiatives throughout Hawaii. Guam, Commonwealth of the Northern Mariana Islands. American Samoa, Florida, Puerto Rico, and the U.S. Virgin Islands. Most of these entities have developed local CRIs that are now well under way and promise to serve as models for development of local or communitybased initiatives elsewhere in the United States and in other countries. As an example. Guam 's local CRI activities were the focus of special sessions at the ICRI workshop in the Philippines, and much of the ICRI "Call to Action" and "Framework for Action" can be traced to these earlier U.S. regional workshop efforts.

\section{Conclusions and Recommendations}

Coral reefs ecosystems have formed in $>100$ countries around the world. An overview of the status of these ecosystems reveal that many are under threat or are being degraded as a result of chronic human derived activities and pollution, especially for coral reef's near population centers. Negative impacts also occur at many remote reefs. and natural disturbances may be exacerbating damage to coral reefs when superimposed over chronic human degradation of coral reefs. The impacts of widespread degradation of coral reefs are difficult to predict accurately and to circumvent because of a paucity of critical information.

Biodiversity associated with coral reefs is difficult to assess because of a dearth of reliable taxonomic information, stemming from an appalling lack of support for academic taxonomists in the last few decades on a world scale (see Maragos et (al., 1995). There is an obvious need for training of appropriate systematists. For species that are better known. such as those that are frequently harvested, there is need for more information on life history cycles so that their populations can be studied holistically rather than piecemeal on individual reefs. Applying this information to questions such as where to develop and implement marine and coastal protected areas (see Eichbaum et al., 1996) will require more information on the distribution and status of coral reef communities.

Many nongovernmental groups have been at the forefront in local implementation of various coral reef monitoring efforts. These grassroots efforts should be applauded and encouraged. However, long-term nationally and globally coordinated coral reef monitoring programs are essential to manage, archive, translate, and transfer data to scientists, managers, and other interest groups.
Within the United States. NOAA is developing a nationally coordinated coral reef monitoring program to be implemented in 1996 and is actively pursuing partnerships with other agencies (such as the National Park Service and the Environmental Protection Agency) and volunteer interest groups (such as American Oceans. The Nature Conservancy, REEF, and Reefkeeper) in this effort. Globally, ICRI has committed to developing such an effort through the IOC.

Until the present decade it was not even possible to evaluate coral reefs on a global basis nor assess the extent of degradation. However, the UNCED at Rio in 1992, the ICRI launched in 1994. the upcoming review of the global status of coral reefs by scientists at the June 1996 meeting in Panama, and the proposed Year of the Reef in 1997 have launched a new era of coordinated scientific inquiry into the status and improved management of the world's coral reefs. Clearly scientists need to be better organized and mobilized to respond to these above challenges including exerting sufficient influence over the direction of the ICRI and other international initiatives involving coral reefs. The next few years hold great promise in refining our goals and needs for better protection of coral reefs into the next millennium.

The long-term vision for the Coral Reef Initiative may be viewed as a global effort to conserve and restore coral reef ecosystems at local levels for the use and enjoyment of future generations. The U.S. CRI will build on existing activities and programs through partnerships and, where appropriate, develop new activities. Both the U.S. and International CRIs are striving to reverse the trend toward degradation of these valuable ecosystems. creating a global partnership to resolve problems. and to increase the capacity of countries for management and sustainable use. A strong commitment to the U.S. CRI will improve domestic programs that will serve as models for management of coral reef ecosystems as part of sustainable development strategies having global applications. The CRI will also provide linkages between domestic and international programs so that U.S. and foreign coral reef management strategies will have a basis in sound science and provide for sustainable economies. communities, and environmental health. and develop new partnerships among all stike holders.

\section{References}

Alino. P.M.. 1983: The effect of mine tailnges on the structure of coral communties in Toledo. Cebu. M.S. thesis. Mitrine Science Institute, University of the Philippunes. Queson City. 104 pp.

Anonymous. 1995: East Astan regional report on the issues and activities associaned with coral reefs and related ecosystems, prepared for the 1995 International Coral Reef Initrative Workshop. Dumaguete City. Philippines. May 1995. unpublished. $24 \mathrm{pp}$.

Bital. J. and W.W. Kuhnhold. 1980): Marme oil pollutuon in
The long-term vision

for the Coral Reef

Initiative may be

viewed as a global

effort to conserve

and restore coral reef

ecosystems at local

levels for the use

and enjoyment of

future generations. 
Southeast Asia. South China Sea Fisheries Development and Coordinating Programme. SCS/80/WP/92 (Revised). $115 \mathrm{pp}$

Cardellina, J.H., 1986: Marine natural products as leads to new pharmaceutical and agrochemical agents. Pure \& Appl. Chem., 58, 365-364.

Crosby, M.P., S.F. Drake, C.M. Eakin, N.B. Fanning, A. Paterson, P.R. Taylor and J. Wilson, 1995: The United States Coral Reef Initiative: an overview of the first steps. Coral Reefs, 14, 1-3.

and J.E. Maragos, 1995: The United States Coral Reef Initiative. In: Marine and Coastal Biodiversity in the Tropical Island Pacific Region. Vol. I: Species Systematics and Information Management Priorities. J.E. Maragos, M.N.A. Peterson, L.G. Eldredge, J.E. Bardach and H.F. Takeuchi, eds. East West Center, Honolulu, HI, 303-316.

Dana, J.D. 1872: Corals and coral islands. 398 pp.. 80 figs.. I pl.

Darwin. C., 1842: The structure and distribution of coral reefs, being the first part of the geology of the voyage of the Beagle, under the Command of Capt. Fitzroy, during the years 1832-36: London. 214 pp.. 2 pls. figs.

Eichbaum, W.M., M.P. Crosby, M.T. Agardy and S.A. Laskin, 1996: The role of marine and coastal protected areas in the conservation and sustainable use of biological diversity. Oceanography, $9, \mathrm{xx}-\mathrm{xx}$.

Ferrer, E.M., 1991: Territorial use rights in fisheries and the management of artificial reefs in the Philippines. In: Towards An Integrated Management of Tropical Coastal Resources. L.M. Chouo. T.-E. Chua. H.W. Khoo. P.E Lim, J.N. Paw. G.T. Silvestre, M.J. Valencia, A.T White and P.K. Wong, eds. ICLARM Conf. Proc. 22,455 pp., 299-302.

Fouda. M.M.. 1995: Regional report, Middle East Seas: issues and activities associated with coral reefs and related ecosystems. Prepared for the 1995 International Coral Reef Initiative Workshop, Dumuguete City, Philippines. May $1995.50 \mathrm{pp}$.

Glynn. P.W.. 1993: Monsoonal upwelling and episodic Acanthaster predation as probable controls of coral reef distribution and community structure in Oman, Indian Ocean. Atoll Res. Bull., 379, 1-65.

Gomez, E.D.. 1978: The Philippine marine environment 1978 Marine pollution and degradation of the ecosystems. Paper presented to the Fourth Symposium of the Cooperative Study of the Kuroshio and Adjacent Regions. Tokyo.

1980: Status report on research and degradation problems of the coral reefs of the East Asian Seas. Paper presented at the Meeting of Experts to Review the Draft Action Plan for the East Asian Sea, Baguio, Philippines. 17-21 June 1980. UNEP/WG.41/INF. 14 South China Sea Fisheries Development and Coordinating Programme, Manila, $68 \mathrm{pp}$.

Goreau, T.F. and J.W. Wells, 1967: The shallow water Scleractinia of Jamaica: revised list of species and their vertical distribution range. Bull. Mar. Sci. Gulf Carib., 17, $442-454$

Helfrich. P. and S.J. Townsley, 1965: Influence fo the sea. In: Man's Place in the Island Ecosystem. F.R. Fosberg, ed. 10th Pac. Sci. Cong. (1961). Bishop Mus. Press. Honolulu. 264 pp.. $39-56$.

Hughes, T.P., 1994: Catastrophes, phase shifts and large-scale degradation of a Caribbean coral reef. Science. 265. $1547-1551$

Kulbicki, M., 1992: Distribution of the major life-history strategies of coral reef fishes across the Pacific Ocean. In: Proceedings of the Seventh International Coral Reef Symposium. Guam. 1992, vol. 2. 908-919.

Lopez, E.. G.A. Gill. G. Camprasse, S. Camprasse and F. Lalier, 1989: Soudure sans transition (octecassimilations) entre l'os maxillaire humain et un implant dentaire compact en calite naturelle d'invetebres marins.
Comptes-Rendus Hebdomadaires des Seances de l'Academie des Sciences, 309. 203-210.

Lopez, M.D.G., 1985: Notes of traditional fisheries in the Philippines. In: The Traditional Knowledge and Management of Coastal Svistems in Asia and the Pacific. K. Ruddle and R.E. Johannes, eds. United Nationals Educational, Scientific and Cultural Organization. Regional Office for Science and Technology for Southeast Asia, Jakarta, Indonesia, 313 pp. 191-206.

Maragos, J.E., 1992: Restoring coral reefs with emphasis on Pacific reefs. In: Restoring the Nation's Marine Environment. G.W. Thayer, ed. Maryland Sea Grant College, College Park Maryland, 141-221.

and P.F. Holthus. A preliminary status report on the coral reefs of the insular tropical Pacific. In: Proceedings of the Workshop on Marine and Cocistal Biodiversity in the Tropical Island Pacific Region. II. Population Development and Conservation Priorities, 7-9 November 1994, Honolulu. L.C. Eldredge. J.E. Maragos, and P.F. Holthus, eds. East-West Center, Honolulu. In press. M.N.A. Peterson, L.C. Eldredge, J.E. Bardach and H.F. Takeuchi. eds. 1995: Marine and Coastal Biodiversity in the Tropical Island Pacific Region. Vol. I: Species Systematics and Information Management Priorities, 2-4 November 1994, Honolulu. East-West Center, Honolulu, 424 pp.

Marshall. A.T., 1996: Calcification in hermatypic and ahermatypic corals. Science, 271, 6.37-639.

McManus, J.W.. 1988. Coral reefs of the ASEAN region. Ambio, 17, 189-193.

1996: Social and economic aspects of reef fisheries and their management. In: Coral Reef Fisheries. N. Polunin and C. Roberts, eds. Chapman \& Hall, New York. In press.

C. Nanola, R. Reyes and K. Kesner, 1992: Resource Ecology of the Bolinao Coral Reef System. ICLARM Studies and Reviews, $117 \mathrm{pp}$.

McManus, L.T. and T.-E. Chua. 1990: The coastal environmental profile of Lingayen Gulf, Philippines. ICLARM Technical Reports 22. International Center or Living Aquatic Resources Management, Manila, Philippines, $69 \mathrm{pp}$.

National Science and Technology Council. 1995: Biotechnology for the 21 st Century: New horizons. U.S. Govt. Printing Office, Washington, DC. $89 \mathrm{pp}$.

Newman, H. and C.S. Chuan. 1994: Transplanting a coral reef: a Singapore community project. Coastal Management in Tropical Asia, 3, 11-14.

Norse. E.A., 1993: Global Marine Biological Diversity. Island Press. Washington. DC, $383 \mathrm{pp}$.

Odum, H.T., R.P. Cuzon du Rest, R.J. Beyers and C. Allbaugh. 1959: Diurnal metabolism, total phosphorus, Ohle anomaly, and zooplankton diversity of abnormal marine ecosystems of Texas. Univ. Texas Inst. Mar. Sci. Pub., 9. 404-453.

Pauly, D., 1990: On Malthusian overfishing. Naga. ICLARM Q. $13,3-4$.

D.G. Silvestre and I.R. Smith. 1989; On development, fisheries and dynamite: a brief review of tropical fisheries management. Nat. Resour. Modeling. 3, 307-329.

Pomeroy, R.S. and M.J. Williams, 1994: Fisheries co-management and small-scale fisheries: a policy brief. International Center for Living Resources Management, Manila. $15 \mathrm{pp}$.

Rogers, C.S. 1985: Degradation of Caribbean and Western Atlantic coral reefs and decline of associated fisheries. In: Proceedings of the Sixth International Coral Reef Symposium, 6, 491-496.

Roux, F.X., D. Brasnu, B. Loty, B. George and G. Fuillemin, 1988: Madreporic coral: a new bone graft substitute for cranial surgery. J. Neurosurg. $69,510-513$.

Salm, R.V.. 1993: Coral reefs of the Sultanate of Oman. Atoll Res. Bull., 380, 1-85.

Santos, L.M., 1988: Fish quality in the Philippines. In Posthanest Fishery Losses. M.T. Morrissey, ed. Pro- 
ceedings of an international workshop, 12-16 April 1987. University of Rhode Island, Kingston, RI, 250) pp.. 73-86. International Center for Marine Resource Development, Kingston, Rhode Island.

Smith. A., 1995: Pacific Ocean regional report on the issues and activities associated with coral reefs and related ecosystems. Prepared for the 1995 International Coral Reef Initiative Workshop, Dumaguete City, Philippines, May 1995, unpublished. $37 \mathrm{pp}$.

Smith, S.R. and J.C. Ogden, eds., 1993: Status and recent history of coral reefs at the CARICOMP network of Caribbean marine laboratories. In: Proceedings at the Colloquium on Global Aspects of Coral Reefs: Health. Hazards, and History: Rosenstiel School of Marine and Atmospheric Science, University of Miami. Miami, 73-76.

Talbot, F.H., 1994: Coral reef protected areas: what are they worth? In: Marine Protected Areas and Biosphere Re'serves: 'Towards a New Paradigm.' D.J. Brunkhorst. ed. Australian Nature Conservation Agency, Canberrat. Australia, 40-44.

Veron, J.E.N., 1986: Corals of Australia and the Inde-Pacific: University of Hawaii Press, Honolulu. 644 pp. , 1992: Conservation of biodiversity: a critical time for the hermatypic corals of Japan. Coral Reefs, 11, 13-21. 1993: Corals of Alstralia and the Indo-Pacific. University of Hawaii Press. Honolulu, 64t pp.

Wells, J.W. 1957: Coral reefs. In: Treatise on Marine Ecology and Paleo-ecology. J.W. Hedgpeth. ed. Geol. Soc. Amer. Mem. No. 67, vol. I, 1296 pp., 609-63I.

White, A.T. and A. Rajasuriya, 1995: South Asian Regional Report on the issues and activities associated with coral reefs and related ecosystems. Prepared for the 1995 International Workshop on Coral Reefs, Dumaguete City, Philippines, May 1995, unpublished, 34 pp.

Woodley. J.D. 1995: Tropical Americas regional report on the issues and activities associated with coral reefs and related ecosystems. Prepared for the 1995 International Coral Recf Initiative Workshop, Dumaguete City, Philippines, May 1995, unpublished, 64 pp.

Yap, H.T. and E.D. Gomez, 1985: Coral reefs degradation and pollution in East Asia Seas region. In: Environment and Resources in the South Pacific: a Regional Approach. D.L. Dahl and J. Carew-Reid. eds. UNEP Regional Seas Reports and Studies No. 69 UNEP Regional Programme, $185-207$. 